\title{
Effects of Triiodothyronine on Retention of $\beta$-Adrenergic Responsiveness of Voltage-Gated Transmembrane Calcium Current during Culture of Ventricular Myocytes from Neonatal Rabbits
}

\author{
KEVIN M. SHANNON, THOMAS S. KLITZNER, FUHUA CHEN, AND CORNELIS VAN DOP \\ Department of Pediatrics, University of California Los Angeles School of Medicine, Los Angeles, \\ California 90095
}

To study the effects of triiodothyronine $\left(\mathrm{T}_{3}\right)$ on responsiveness of L-type calcium currents to $\beta$-adrenergic stimulation in neonatal hearts, ventricular myocytes were isolated from neonatal rabbits and cultured in medium containing $10 \%$ fetal bovine serum to which $\mathrm{T}_{3}$ had been added to achieve either hypothyroid, euthyroid, or hyperthyroid conditions, as assessed by measurement of free $T_{3}$ concentrations. During a 24-h culture period, the striated rod-shaped myocardial cells progressively assumed a stellate shape with reduced surface area; however, the rate constants for diffusion of $\mathrm{Na}^{+}$from a microelectrode pipette into the cells remained unchanged. Voltage-dependent characteristics of L-type calcium currents as assessed by whole-cell voltage clamp studies were also unchanged after culture with various concentrations of free $T_{3}$. By contrast, the stimulation of voltage-gated transmembrane calcium current from baseline by isoproterenol was reduced $(p<0.05)$ in hypothyroid cells $(15 \pm 8 \% ; n=14)$ compared with either euthyroid $(86 \pm 15 \% ; n=18)$, hyperthyroid $(54 \pm 16 \% ; n=12)$ or freshly isolated $(50 \pm 12 \% ; n=10)$ myocytes. The differences in $\beta$-adrenergic responsiveness of voltage-gated transmembrane calcium current to isoproterenol between euthyroid, hyperthyroid, and freshly isolated cells were not significant $(p>0.05)$. These results indicate that retention of $\beta$-adrenergic responsiveness of voltage-gated transmembrane calcium current in neonatal cardiac myocytes depends on physiologic amounts of active thyroid hormone. Our culture method for neonatal cardiac myocytes will be useful for studying physiologic modulation of $\beta$-adrenergic responsiveness. (Pediatr Res 37: 277-282, 1995)
G protein, guanine nucleotide-binding coupling protein HEPES, $N$-2-hydroxyethylpiperazine- $N^{\prime}$-2-ethanesulfonic acid $\mathbf{I}_{\mathbf{C a}}$, voltage-gated transmembrane calcium current $\mathbf{T}_{\mathbf{3}}$, triiodothyronine
$\mathbf{T}_{4}$, thyroxine

Inadequate or excessive amounts of thyroid hormone affect both the peripheral vasculature and the ventricular myocardium in vivo (1). Direct effects of thyroid hormone on heart muscle include increasing the rate and force of contraction and decreasing diastolic relaxation time (2). These effects, achieved via nuclear actions of the active form of the thyroid hormone $T_{3}$ are mediated by $T_{3}$ binding to specific nuclear receptors, which function as transcription factors to alter transcription of $\mathrm{T}_{3}$-responsive genes (3). Treatment of euthyroid animals with supplemental $\mathrm{T}_{3}$ alters cellular concentrations of mRNA-

Received July 18, 1994; accepted October 18, 1994.

Correspondence: Cornelis Van Dop, M.D., Ph.D., MDCC 22-315, University of California Los Angeles Medical Center, 10833 Le Conte Ave., Los Angeles, CA 90095-1752.

Supported in part by National Institutes of Health Grants HL-02723 and RR-00865, American Heart Association Grant 93006170, American Heart Association, Greater Los Angeles Affiliate, Grants 1007-FI and 981-CS, and the Variety Club, J. H. Nicholson Endowment. encoding myosin isoforms (4), $\beta$-adrenergic receptors (5), $\mathrm{Ca}^{2+}$-dependent ATPase (6), and $\mathrm{G}$ proteins (7).

In addition, several in vivo and in vitro studies have demonstrated alterations in membrane $\mathrm{Ca}^{2+}$ channel physiology induced by $\mathrm{T}_{3}(8-11)$. Using whole-cell voltage clamp studies of freshly isolated ventricular myocytes from hypothyroid, euthyroid, and hyperthyroid adult guinea pigs, Binah et al. (10) demonstrated increased inward calcium currents, increased outward potassium currents, and shortened action potential after in vivo administration of thyroid hormone. Treatment of cultured chick ventricular myocytes with $\mathrm{T}_{3}$ increased L-type $\mathrm{Ca}^{2+}$ channel density, increased transmembrane calcium flux, and increased intracellular $\mathrm{Ca}^{2+}$ concentration during subsequent treatment with isoproterenol (11). Those studies suggest that the direct effects of $\mathrm{T}_{3}$ on the myocardium result, at least in part, from changes in calcium channel density and $\beta$-adrenergic responsiveness. 
Although diminished $\beta$-adrenergic responsiveness is a pathologic marker of heart failure, cause-and-effect relations between heart failure and decreased $\beta$-adrenergic responsiveness have not been established. To address this question, we sought to develop an in vitro model for investigating the effects of thyroid hormone on retention of $\beta$-adrenergic responsiveness of $\mathrm{I}_{\mathrm{Ca}}$ in cultured cardiomyocytes from euthyroid neonatal rabbits.

\section{METHODS}

Isolation and culture of cardiomyocytes. Ventricular myocytes were isolated as previously described (12) with some modifications. Newborn rabbits (New Zealand White, 2-3 d old) were administered intraperitoneal heparin (1000 U) and pentobarbital $(50 \mathrm{mg})$ before rapid excision of the heart. Hearts were rinsed in Tyrode's solution $(136 \mathrm{mM} \mathrm{NaCl}, 5.4 \mathrm{mM} \mathrm{KCl}$, $0.33 \mathrm{mM} \mathrm{NaH}_{2} \mathrm{PO}_{4}, 1 \mathrm{mM} \mathrm{MgCl}, 10 \mathrm{mM} \mathrm{Na}$-HEPES, pH 7.3, $4 \mathrm{mM}$ mannitol, $0.6 \mathrm{mM}$ thiamine, $10 \mathrm{mM}$ glucose, and $2 \mathrm{mM}$ pyruvic acid) containing $3.5 \mathrm{mM} \mathrm{CaCl}$ and mounted on a sterile Langendorf perfusion apparatus. All perfusion solutions were sterilized by filtering through a $2-\mu \mathrm{m}$ filter, and then oxygenated $\left(100 \% \mathrm{O}_{2}\right)$ and maintained at $37^{\circ} \mathrm{C}$ before use. The coronary arteries were perfused via the aorta with calcium-free Tyrode's solution at $37^{\circ} \mathrm{C}$ using a peristaltic pump $(2.5 \mathrm{~mL} /$ $\mathrm{min}$ ) for $3 \mathrm{~min}$, followed by perfusion at the same rate with Tyrode's solution containing collagenase $(1 \mathrm{mg} / \mathrm{mL}$, type 1 , Sigma Chemical Co., St. Louis, MO) and protease (0.076 $\mathrm{mg} / \mathrm{mL}$, type XIV, Sigma) until the heart was flaccid (7-12 $\mathrm{min})$. The enzyme-containing solution was then flushed from the heart for $3 \mathrm{~min}$ with Tyrode's solution containing $0.1 \mathrm{mM}$ $\mathrm{CaCl}_{2}$. The atria and connective tissue were removed, and the ventricles were teased apart with forceps. Individual ventricular myocytes were dispersed by gentle shaking in Tyrode's solution containing $0.1 \mathrm{mM} \mathrm{CaCl}_{2}$ and filtered through sterile nylon mesh $(\sim 500 \mu \mathrm{m}$ pore size; Fisher Scientific, Pittsburgh, PA) to remove residual connective tissue. The myocytes were then separated from smaller connective tissue cells and debris by sedimentation $(1 \times g$ twice for $90 \mathrm{~min})$. After the second sedimentation, the cell pellet was resuspended in culture medium [minimum essential media with Earle's salts and $25 \mathrm{mM}$ Na-HEPES, pH 7.4, $2 \mathrm{mM}$ glutamine, $500 \mathrm{U} / \mathrm{mL}$ penicillin G, $500 \mu \mathrm{g} / \mathrm{mL}$ streptomycin, and $10 \%$ (vol/vol) fetal bovine serum (Sigma)]. The cells were plated in $75-\mathrm{cm}^{2}$ flasks for $4-6$ $\mathrm{h}$ at $37^{\circ} \mathrm{C}$ to allow attachment of fibroblasts to the plastic flasks. The nonadherent ventricular myocytes were then transferred to $25-\mathrm{cm}^{2}$ tissue culture flasks containing fragments of glass coverslips that had been pretreated for $4-6 \mathrm{~h}$ with culture media containing $10 \%$ fetal bovine serum to promote attachment of myocytes. Cells were plated at a density of 2-3 $\times 10^{6}$ cells per $25-\mathrm{cm}^{2}$ flask with medium, to which appropriate concentrations of $T_{3}$ (Sigma) had been added. The cells were maintained at $37^{\circ} \mathrm{C}$ in a humidified $95 \%$ air-5\% $\mathrm{CO}_{2}$ atmosphere.

Free $T_{3}$ assay. Culture medium was collected from each culture flask at the time the cultured cells were used for voltage clamp studies and stored at $-20^{\circ} \mathrm{C}$ until the free $\mathrm{T}_{3}$ assay was performed. Free $T_{3}$ was measured in each sample using a competitive binding assay (Coat-a-Count, Diagnostic Products Corp., Los Angeles, CA). The interassay coefficient of variation for this assay was approximately 5\%, and limits of detection were 0.3 and $155 \mathrm{pM}$.

Current measurements. Transmembrane currents were measured using the whole-cell voltage clamp technique, similar to that described by Hamill et al. (13). All voltage clamp studies of cultured cells were performed between 22 and $28 \mathrm{~h}$ after plating of the cells into culture flasks. Cells chosen for whole-cell voltage clamp studies were adherent to the glass coverslip, quiescent, and lacked apparent contact with adjacent cells. To perform voltage clamp studies, a glass coverslip with adherent myocytes was removed from the culture flask, placed in a $0.5 \mathrm{~mL}$ well on the stage of an inverted microscope (Zeiss, Thornwood, NY), and rinsed with Tyrode's solution containing $0.1 \mathrm{mM} \mathrm{CaCl}_{2}$. Tansmembrane currents were measured during voltage clamp steps using an EPC-7 patch-clamp amplifier (Adams/List, Great Neck, NY). Currents were filtered at $1 \mathrm{kHz}$ using an eight-pole Bessel filter (Frequency Devices, Haverhill, MA), digitized using the Axolab 1100 data-acquisition system, and analyzed using pCLAMP software (Axon Instruments Inc., Foster City, CA).

Capacitance measurements were made as previously described by Hunyh et al. (12) immediately after establishing a whole-cell seal.

Cellular dialysis. The rate of dialysis of the cell with internal pipette solution was determined using the method described by Wetzel et al. (14). After the formation of a stable seal, 64 sequential voltage clamps from -120 to $0 \mathrm{mV}$ were performed at 4-s intervals. Because the internal solution $(60 \mathrm{mM} \mathrm{NaCl}, 46$ $\mathrm{mM} \mathrm{CsCl}, 20 \mathrm{mM}$ Cs-HEPES, pH 7.1, $1 \mathrm{mM} \mathrm{MgCl} 2,1 \mathrm{mM}$ $\mathrm{CaCl}_{2}, 14 \mathrm{mM}$ EGTA, and $5.5 \mathrm{mM} \mathrm{Mg}$-ATP) and external solution $(60 \mathrm{mM} \mathrm{NaCl}, 75 \mathrm{mM} \mathrm{CsCl}, 10 \mathrm{mM}$ Cs-HEPES, $\mathrm{pH}$ $7.3,1 \mathrm{mM} \mathrm{MgCl}, 1 \mathrm{mM} \mathrm{CaCl}, 0.1 \mathrm{mM} \mathrm{CdCl}_{2}$, and $10 \mathrm{mM}$ glucose) contained equal concentrations of $\mathrm{Na}^{+}$, the transmembrane $\mathrm{Na}^{+}$current at $0 \mathrm{mV}$ decreased to zero as $\mathrm{Na}^{+}$ions diffused from the microelectrode into the cell to progressively reduce the transmembrane concentration gradient of $\mathrm{Na}^{+}$. Transmembrane currents carried by potassium and calcium ions were blocked by cesium and cadmium ions, respectively. The time constant for diffusion of $\mathrm{Na}^{+}$into the cell was determined using nonlinear least-squares regression (BMDP software, University of California Los Angeles).

Measurement of transmembrane calcium currents. For these experiments, the internal solution contained $96 \mathrm{mM}$ $\mathrm{CsCl}, 20 \mathrm{mM}$ Cs-HEPES, pH 7.1, 14 mM EGTA, $1 \mathrm{mM} \mathrm{CaCl}_{2}$, $6 \mathrm{mM} \mathrm{MgCl}, 10 \mathrm{mM}$ tetraethylammonium-Cl, and $5 \mathrm{mM}$ ATP, and the external solution contained $135 \mathrm{mM} \mathrm{CsCl}, 1.8$ $\mathrm{mM} \mathrm{Cs}$-HEPES, pH 7.3, $1.8 \mathrm{mM} \mathrm{CaCl}_{2}, 1 \mathrm{mM} \mathrm{MgCl} 2,10 \mathrm{mM}$ glucose, and $0.01 \mathrm{mM}$ tetrodotoxin. Cesium ions and tetrodotoxin were included to block currents carried by potassium and sodium ions, respectively. The relation between peak $\mathrm{I}_{\mathrm{Ca}}$ and depolarization potential was determined by performing voltage steps from an initial holding potential of $-80 \mathrm{mV}$ to a prepulse potential of $-40 \mathrm{mV}$ for $50 \mathrm{~ms}$ followed by a 100 -ms voltage step to test potentials between -30 and $40 \mathrm{mV}$ in $10-\mathrm{mV}$ increments at 5-s intervals. Steady state activation and inactivation curves for $\mathrm{I}_{\mathrm{Ca}}$ were constructed as described by Wetzel 
et al. (15). Steady state activation and inactivation curves were fitted to the Boltzmann equation using nonlinear least-squares regression.

The response of $\mathrm{I}_{\mathrm{Ca}}$ to isoproterenol was determined by performing a series of 18 voltage clamps from a holding potential of $-80 \mathrm{mV}$ to a prepulse potential of $-40 \mathrm{mV}$ for 50 $\mathrm{ms}$, followed by a 100 -ms voltage step to $0 \mathrm{mV}$ at 20 -s intervals. Transmembrane calcium currents were recorded during each voltage step. After the second voltage clamp, $10 \mu \mathrm{M}$ isoproterenol was added. Basal transmembrane calcium current was the average of the peak inward current measured during the two voltage clamp steps preceding addition of isoproterenol. The maximal isoproterenol-stimulated $\mathrm{I}_{\mathrm{Ca}}$ was the largest peak transmembrane current during the 16 voltage steps performed after the solution change. Peak $\mathrm{I}_{\mathrm{Ca}}$ achieved a new steady state within $5 \mathrm{~min}$ after addition of isoproterenol. The response to isoproterenol was expressed as the percent increase in maximal peak $\mathrm{I}_{\mathrm{Ca}}$ with isoproterenol compared with maximal peak $\mathrm{I}_{\mathrm{Ca}}$ before addition of isoproterenol. All electrophysiologic studies were performed at $23^{\circ} \mathrm{C}$.

Statistical analyses. Results are expressed as mean \pm SEM (number of measurements), unless indicated otherwise. Statistical significance was determined using the Student-NewmanKeuls multiple range test. Differences were considered significant at $p<0.05$. For comparison of the percent increase in $\mathrm{I}_{\mathrm{Ca}}$ after addition of isoproterenol, a logarithmic transformation of the data was performed before applying the Student-NewmanKeuls multiple-range test.

\section{RESULTS}

Free $T_{3}$ concentrations during myocyte culture. The mean free $\mathrm{T}_{3}$ concentration in plasma obtained from neonatal rabbits (1-3 d old) was $2.0 \pm 0.2 \mathrm{pM}(n=13)$. Free $\mathrm{T}_{3}$ concentration in culture media containing $10 \%$ fetal bovine serum to which no $\mathrm{T}_{3}$ had been added was $0.77 \pm 0.28 \mathrm{pM}(n=12)$. This culture medium was thus considered to provide hypothyroid culture conditions. With addition of $10 \mathrm{pmol} / \mathrm{L} \mathrm{T}_{3}$ to this hypothyroid culture medium, the free $\mathrm{T}_{3}$ concentration increased to $3.5 \pm 1.2 \mathrm{pM}(n=6)$, and this culture medium was considered to provide euthyroid conditions during cell culture. Finally, addition of $10 \mathrm{nmol} / \mathrm{L} \mathrm{T}_{3}$ yielded a free $\mathrm{T}_{3}$ concentration beyond the range of the assay $(>154 \mathrm{pM} ; n=12)$. Because of the dynamic state of $T_{3}$ binding to serum proteins, better quantification of free $T_{3}$ concentration in the media to which $10 \mathrm{nM} \mathrm{T}_{3}$ had been added was not possible. This medium was thought to provide hyperthyroid culture conditions.

Cellular morphology. Freshly isolated ventricular cells displayed a striated rod shape and had an eccentrically placed nucleus under phase-contrast microscopy $(\times 450)$. Approximately $4 \mathrm{~h}$ after initiation of culture, a progressive loss of striations and loss of rod shape commenced, and by $12 \mathrm{~h}$ of culture, the cells were spherical in shape with no visible striations. After $24 \mathrm{~h}$ of culture, the cells had developed pseudopod-like attachments to the plate and had assumed a stellate shape; no striated rod-shaped cells remained, and most
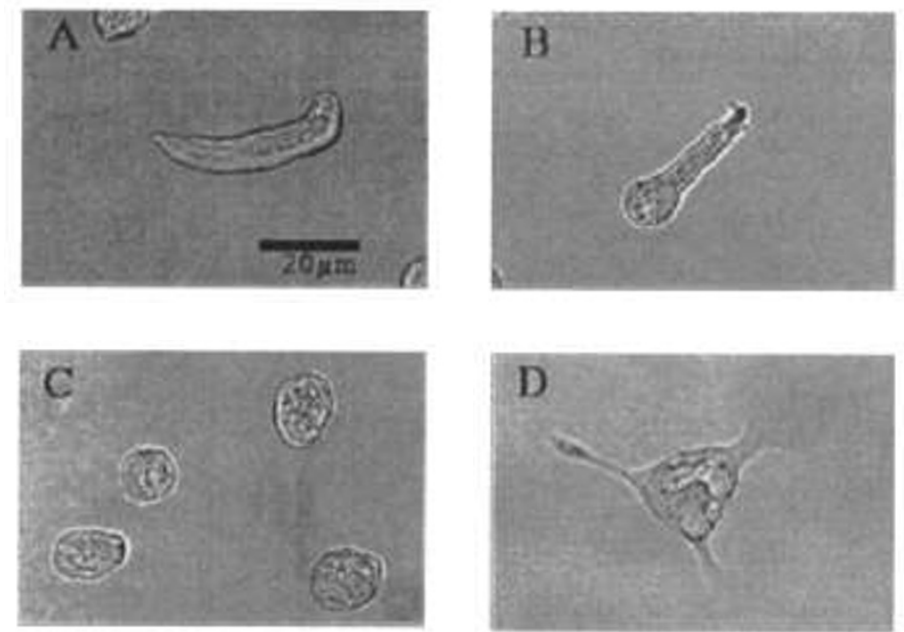

Figure 1. Photomicrographs of cardiomyocytes. Ventricular myocytes from neonatal rabbits immediately after isolation $(A)$, and after culture in euthyroid medium for $4 \mathrm{~h}(B) 12 \mathrm{~h}(C)$ and $24 \mathrm{~h}(D)$ as described in "Methods."

cells were attached to the plastic flasks or glass coverslips (Fig. 1).

Cellular surface area. As the capacitance of biologic membranes is relatively constant $\left(1 \mu \mathrm{F} / \mathrm{cm}^{2}\right)(16)$, capacitance was used as a measure of cellular surface area. Mean capacitance of the freshly isolated myocytes was $18.0 \pm 1.2 \mathrm{pF}(n=14)$ and was $14.0 \pm 2.4 \mathrm{pF}, 10.7 \pm 1.4 \mathrm{pF}$, and $10.8 \pm 1.9 \mathrm{pF}$ for hypothyroid $(n=23)$, euthyroid $(n=14)$, and hyperthyroid $(n=14)$ cells, respectively. The cells cultured under euthyroid and hyperthyroid conditions were thus slightly smaller than the freshly isolated cells $(p<0.01)$, but cultured cells did not differ in size regardless of the free $T_{3}$ concentration present in the culture medium.

Whole-cell voltage clamp characteristics of myocytes. To determine whether the altered cell morphology that developed during short-term culture was associated with changes in the electrophysiologic characteristics of the ventricular myocytes, we measured rate constants for dialysis of the cell with internal pipette solution. The rate of loss of the transmembrane $\mathrm{Na}^{+}$ gradient during diffusion of the $\mathrm{Na}^{+}$ion from the pipette solution was determined for freshly isolated and cultured myocytes. Both cultured cells and freshly isolated cells demonstrated exponential decay curves. The time constants for loss of the transmembrane potential were not different among cells cultured in euthyroid ( $30.7 \pm 7 \mathrm{~s} ; n=7)$, hypothyroid (35.6 \pm $5 \mathrm{~s} ; n=12)$, or hyperthyroid $(33.0 \pm 3.6 \mathrm{~s} ; n=5)$ conditions and freshly isolated cells $(37.3 \pm 6.0 \mathrm{~s} ; n=7)$. In all groups, loss of the transmembrane $\mathrm{Na}^{+}$gradient was $80 \%$ complete within $4 \mathrm{~min}$. These results indicate that changes in the cell morphology that occur in these cells do not drastically affect the ability to control the intracellular ionic environment of ventricular myocytes using the whole-cell voltage clamp technique.

Transmembrane calcium currents. The relation between maximal $\mathrm{I}_{\mathrm{Ca}}$ and transmembrane voltage in cultured myocytes was similar to that for freshly isolated cells (Fig. 2). Maximal $\mathrm{I}_{\mathrm{Ca}}$ in all cells occurred at transmembrane potentials between -10 and $0 \mathrm{mV}$. Steady state activation and inactivation curves for $I_{\mathrm{Ca}}$ (Fig. 3) displayed no significant difference between cell 

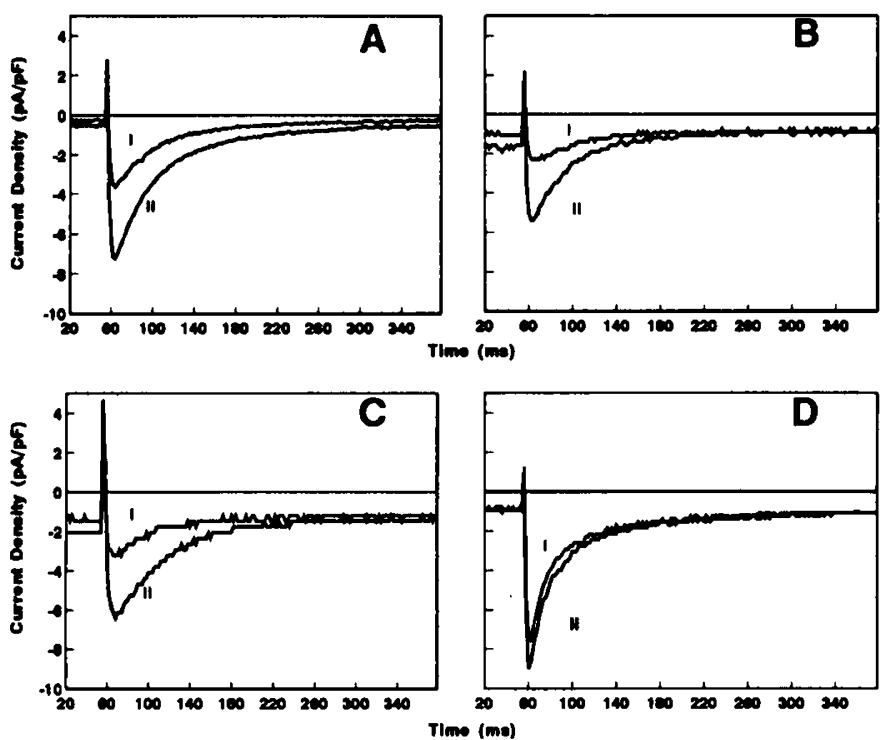

Figure 2. $\mathrm{I}_{\mathrm{Ca}}$ recordings from ventricular myocytes. Representative $\mathrm{I}_{\mathrm{Ca}}$ standardized to cell surface area for a freshly isolated myocyte $(A)$ and myocytes cultured for $24 \mathrm{~h}$ with euthyroid conditions $(B)$, hypothyroid conditions $(C)$, and hyperthyroid conditions $(D)$. In each panel $\mathrm{I}_{\mathrm{Ca}}$ was measured during a 400 -ms depolarization to $0 \mathrm{mV}$ before $(I)$ and during (II) exposure of the cell to $10 \mu \mathrm{M}(-)$ isoproterenol.
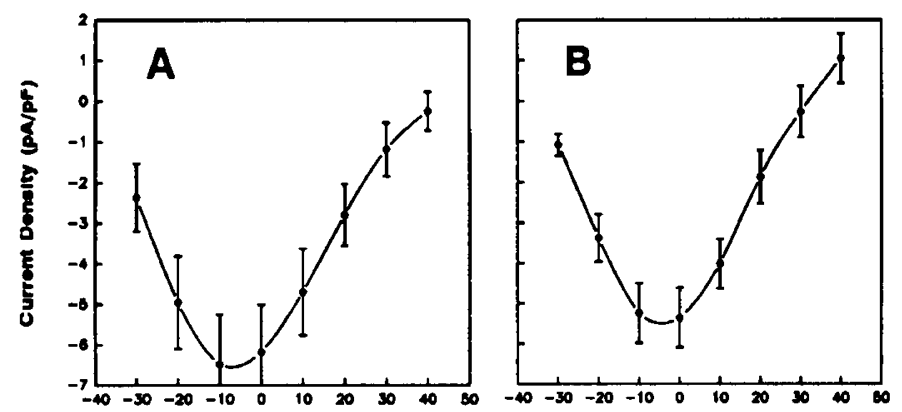

Membrene Potentlal (mV)

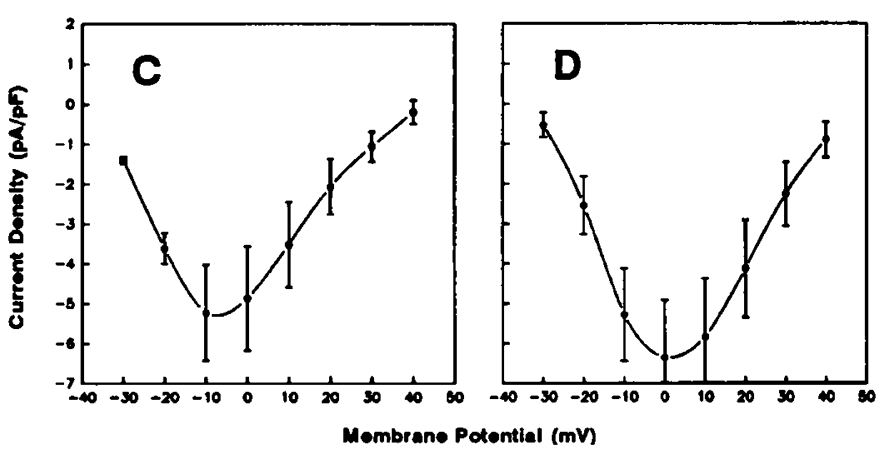

Figure 3. Plot of peak $\mathrm{I}_{\mathrm{Ca}} v s$ applied transmembrane voltage in ventricular myocytes. Panels indicate results for freshly isolated myocytes $(A, n=18)$ and myocytes cultured for $24 \mathrm{~h}$ with euthyroid conditions $(B, n=18)$, with hyperthyroid conditions $(C, n=12)$, and with hypothyroid conditions $(D, n=$ $10)$.

groups. Specifically, the membrane potential producing halfmaximal activation of $\mathbf{I}_{\mathrm{Ca}}$, half-maximal inactivation of $\mathrm{I}_{\mathrm{Ca}}$, and the dependence of $\mathrm{I}_{\mathrm{Ca}}$ activation on transmembrane voltage, as determined from the fitted Boltzmann equation, were similar for all the experimental groups (Table 1 and Fig. 4). The dependence of $\mathrm{I}_{\mathrm{Ca}}$ inactivation on transmembrane voltage was slightly higher in freshly isolated cells $(-7.2 \pm 0.3 \mathrm{mV})$
Table 1. Calculated kinetic constants for steady state activation and inactivation of $I_{C a}$

\begin{tabular}{ccccc}
\hline Treatment & $\mathrm{K}_{\mathrm{A}}$ & $\begin{array}{c}\mathrm{V}_{\mathrm{hA}} \\
(\mathrm{mV})\end{array}$ & $\mathrm{K}_{\mathrm{I}}$ & $\mathrm{V}_{\mathrm{hI}}(\mathrm{mV})$ \\
\hline $\begin{array}{c}\text { Freshly isolated cells } \\
(n=7)\end{array}$ & $5.8 \pm 0.3$ & $-23 \pm 3$ & $-7.2 \pm 0.3^{*}$ & $-40 \pm 2$ \\
$\begin{array}{c}\text { Euthyroid culture } \\
\quad(n=10)\end{array}$ & $6.0 \pm 0.4$ & $-17 \pm 1$ & $-5.7 \pm 0.4$ & $-34 \pm 2$ \\
$\begin{array}{c}\text { Hypothyroid culture } \\
(n=14)\end{array}$ & $6.5 \pm 0.2$ & $-20 \pm 1$ & $-5.1 \pm 0.1$ & $-36 \pm 1$ \\
$\begin{array}{c}\text { Hyperthyroid culture } \\
(n=14)\end{array}$ & $6.0 \pm 0.4$ & $-19 \pm 2$ & $-5.4 \pm 0.2$ & $-33 \pm 2$ \\
\hline
\end{tabular}

Values for $\mathrm{K}_{\mathrm{A}}, \mathrm{K}_{\mathrm{l}}, \mathrm{V}_{\mathrm{hA}}$, and $\mathrm{V}_{\mathrm{h}}$ were determined by fitting the data shown in Figure 4 to the Boltzmann equation $\left(F_{x}=\left[1+e^{(V-V h) / K}\right]^{-1}\right) . K_{A}$ and $K_{I}$ are exponential coefficients from the Boltzmann equation for activation and inactivation constants, respectively. $\mathrm{V}_{\mathrm{hA}}$ and $\mathrm{V}_{\mathrm{hl}}$ are transmembrane potentials at half-maximal activation and half-maximal inactivation, respectively.

* Significant difference $(p<0.05)$ compared with other experimental groups.
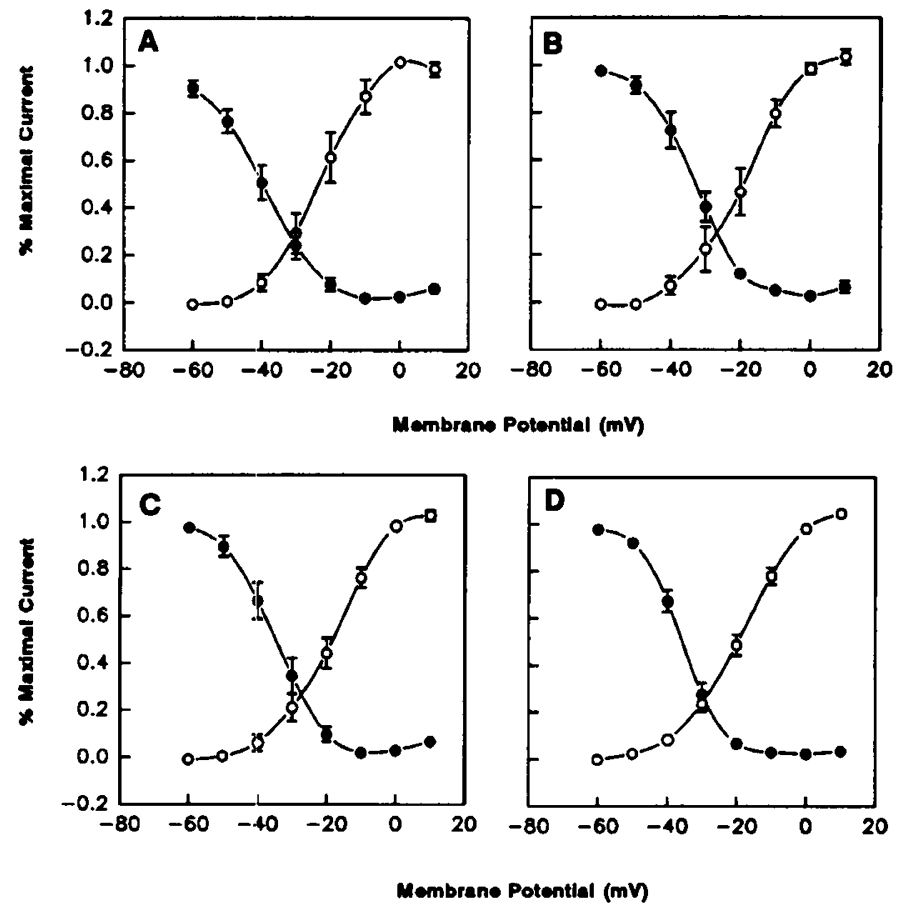

Figure 4. Plots of percent maximal $\mathrm{I}_{\mathrm{Ca}} v s$ transmembrane voltage. Calculations were performed as described by Wetzel et al. (15). Filled circles indicate the proportion of calcium channels that are closed after depolarization from each transmembrane voltage to $0 \mathrm{mV}$. Open circles indicate the proportion of calcium channels that are open after depolarization from $-80 \mathrm{mV}$ to each transmembrane voltage. Data were obtained from freshly isolated cells $(A, n=$ 7) and from myocytes cultured for $24 \mathrm{~h}$ with euthyroid conditions $(B, n=10)$, hyperthyroid conditions $(C, n=14)$, and hypothyroid conditions $(D, n=14)$.

compared with cultured cell groups $(-5.1 \pm 0.1,-5.4 \pm 0.2$, and $-5.7 \pm 0.4 \mathrm{mV}$ for cells cultured under hypothyroid, hyperthyroid, and euthyroid conditions, respectively). These results demonstrate that kinetics for the transmembrane calcium current are not significantly altered in ventricular myocytes during culture and are unaffected by alterations in free $\mathrm{T}_{3}$ concentrations.

Response to isoproterenol. The response of $\mathrm{I}_{\mathrm{Ca}}$ to isoproterenol was significantly greater in freshly isolated cells $(50 \pm$ $12 \% ; n=10)$ and in cells cultured under euthyroid ( $86 \pm 15 \%$; 
$n=18)$, or hyperthyroid $(54 \pm 16 \% ; n=12)$ conditions than in cells cultured under hypothyroid conditions $(15 \pm 8 \% ; n=$ 14). Differences in the degree of stimulation of $\mathrm{I}_{\mathrm{Ca}}$ by isoproterenol between freshly isolated myocytes and cells cultured under either euthyroid or hyperthyroid conditions were not significant. These results indicate that maintenance of the responsiveness of $I_{C a}$ in cultured ventricular myocytes to $\beta$-adrenergic stimulation requires physiologic concentrations of $T_{3}$.

\section{DISCUSSION}

We have developed a method for in vitro culture of ventricular cardiomyocytes from neonatal rabbits and demonstrated that physiologic concentrations of free $\mathrm{T}_{3}$ maintain responsiveness of myocardial $\mathrm{I}_{\mathrm{Ca}}$ to $\beta$-adrenergic stimulation during short-term culture. Neonatal ventricular myocytes cultured in hypothyroid conditions have a diminished response to $\beta$-adrenergic stimulation. These data suggest that providing physiologic concentrations of free $T_{3}$ during short-term culture is important for preserving normal calcium channel sensitivity to $\beta$-adrenergic agonists.

$T_{3}$ concentrations during cell culture. $T_{4}$, the primary circulating thyroid hormone in mammals, is the prohormone for $T_{3}$, which has four to 10 times greater affinity for thyroid hormone receptors and is the most physiologically important thyroid hormone (17). The conversion of $T_{4}$ to $T_{3}$ is catalyzed by the enzyme iodothyronine $5^{\prime}$-deiodinase, an enzyme that occurs in most tissues. However, the heart uses $T_{3}$ that is derived largely from the circulation rather than producing $T_{3}$ itself (17). Therefore, to circumvent any problems related to limited conversion of the prohormone $\mathrm{T}_{4}$ to $\mathrm{T}_{3}$ by cardiomyocytes, we used $T_{3}$ in our studies. As greater than $99 \%$ of $T_{3}$ in the circulation is bound to plasma-binding proteins and biologically unavailable (17), only free unbound concentrations of $\mathrm{T}_{3}$ were assessed in our studies. The free concentration of $\mathrm{T}_{3}$ $(0.77 \pm 0.28 \mathrm{pM})$ in minimum essential media with added $10 \%$ fetal bovine serum was significantly lower than the free $T_{3}$ concentration measured in plasma from neonatal rabbits $(2.0 \pm$ $0.2 \mathrm{pM}$ ), as well as lower than the concentrations reported for human infants at birth $(2.0-3.5 \mathrm{pM})(18,19)$ or at $2-8 \mathrm{~d}$ of age $(5.7-7.1 \mathrm{pM})(18-20)$. Thus culture medium unsupplemented with $\mathrm{T}_{3}$ provides a hypothyroid environment for in vitro culture of the ventricular myocytes. By contrast, the free $T_{3}$ concentration present in our euthyroid medium is slightly greater than the concentration of $T_{3}$ measured in the plasma of neonatal rabbits, which may have been artificially lowered by the presence of heparin (data on the effects of heparin on free $T_{3}$ assay provided by Diagnostic Products Corp.).

The effects of added $T_{3}$ on response of $I_{C a}$ to isoproterenol. In contrast to the findings in several previous studies $(10,11)$, we did not find an effect of supraphysiologic $T_{3}$ levels on L-type calcium current density (Table 2) or on the response of $\mathrm{I}_{\mathrm{Ca}}$ to $\beta$-adrenergic stimulation. Kim et al. (11) concluded that $10 \mathrm{nM} \mathrm{T} \mathrm{T}_{3}$ added to serum-free culture medium increases L-type calcium channel number and activity in spontaneously contracting monolayers of chick ventricular myocytes as assessed by dihydropyridine binding and nifedipine-sensitive ${ }^{45} \mathrm{Ca}^{2+}$ uptake, but they did not compare the cultured cells with
Table 2. $I_{C a}$ in cardiomyocytes before and after treatment with isoproterenol

\begin{tabular}{cccc}
\hline Treatment & $\begin{array}{c}\text { Peak } \mathrm{I}_{\mathrm{Ca}} \text { before } \\
\text { isoproterenol } \\
(\mathrm{pA} / \mathrm{pF})\end{array}$ & $\begin{array}{c}\text { Peak } \mathrm{I}_{\mathrm{Ca}} \text { with } \\
\text { isoproterenol } \\
(\mathrm{pA} / \mathrm{pF})\end{array}$ & $\begin{array}{c}\text { Increase in } \mathrm{I}_{\mathrm{Cu}} \\
\text { with isoproterenol } \\
(\%)\end{array}$ \\
\hline $\begin{array}{c}\text { Freshly isolated cells } \\
(n=10)\end{array}$ & $-6.1 \pm 1.3$ & $-8.2 \pm 1.2$ & $50 \pm 12$ \\
$\begin{array}{c}\text { Euthyroid culture } \\
(n=18)\end{array}$ & $-4.4 \pm 0.6$ & $-6.9 \pm 0.7$ & $86 \pm 15$ \\
$\begin{array}{c}\text { Hypothyroid culture } \\
(n=14)\end{array}$ & $-6.5 \pm 0.9$ & $-7.2 \pm 0.9$ & $15 \pm 8^{*}$ \\
$\begin{array}{c}\text { Hyperthyroid culture } \\
(n=12)\end{array}$ & $-5.9 \pm 0.7$ & $-8.7 \pm 1.2$ & $54 \pm 16$ \\
\hline
\end{tabular}

Peak $\mathrm{I}_{\mathrm{Ca}}$ was measured before and during exposure of cells to $10 \mu \mathrm{M}$ $(-)$-isoproterenol, and the percent increase of $\mathrm{I}_{\mathrm{Ca}}$ was calculated for each cell.

* Significant difference $(p<0.05)$ compared with other experimental groups.

freshly isolated cells. By contrast, we measured calcium channel activity directly, without other sources of calcium uptake, e.g. sodium-calcium exchange, before and after culture. By using quiescent myocytes, we eliminated the effects of $T_{3}$ on the strength and rate of contraction, which may secondarily affect calcium uptake. In addition, comparison of contracting and noncontracting ventricular myocytes has revealed differences in cellular morphology (21), levels of the nonstimulatory, noninhibitory guanine nucleotide binding protein designated $\mathrm{G}_{\mathrm{o}} \alpha(22)$, and synthetic rates of proteins (23). Some differences may thus occur between noncontracting and contracting ventricular myocytes during treatment with $T_{3}$. Alternatively, endothelial cells present during culture may secrete growth factors that alter gene expression in the cultured cardiac myocytes.

The mechanism by which responsiveness of $\mathrm{I}_{\mathrm{Ca}}$ to $\beta$-adrenergic stimulation is preserved under euthyroid culture conditions may be related to maintenance of normal expression of one or more components of the cellular signaling cascade that couples cardiac $\beta$-adrenergic receptors to L-type calcium channels. The major components of this signaling pathway are the $\beta$-adrenergic receptors, $G$ protein that stimulates adenylyl cyclase, adenylyl cyclase, and protein kinase A. In addition, changes in other cellular components may indirectly affect this signaling pathway, e.g. muscarinic receptors and $\mathrm{G}$ proteins that inhibit adenylyl cyclase. Cardiac levels of a number of these proteins are affected by thyroid hormone status. Specifically, expression of $\beta$-adrenergic receptor is increased by thyroid hormone (24), and the promoter region of the human gene encoding the $\beta_{1}$-adrenergic receptor contains a consensus thyroid hormone response element and possibly a second thyroid hormone response element (25). Conversely, added thyroid hormone seems to increase the degradation of the cardiac muscarinic receptor in neonatal rat cardiomyocytes (26). Although the expression of the $\alpha$-subunit of $\mathrm{G}$ protein that stimulates adenylyl cyclase in heart does not seem to be modulated by thyroid hormone, cardiac levels of $G$ proteins that inhibit adenylyl cyclase are modulated by thyroid hormone treatment (7). Finally, altered cellular levels of $\beta$-subunits of $G$ proteins can modify $\beta$-adrenergic regulation of $\mathrm{I}_{\mathrm{Ca}}$ in cardiac myocytes from neonatal rabbits (Chen F, Van Dop C, Wetzel 
GT, Lee RH, Friedman WF, Klitzner TS, unpublished observations). In addition, activity of L-type calcium channels in the chick heart is increased by thyroid hormone (11). Thyroid hormone thus modulates expression of numerous proteins involved in mediating cellular responsiveness to $\beta$-adrenergic stimulation. Our finding of the requirement for euthyroid conditions during culture of neonatal cardiomyocytes to maintain cellular responsiveness of $I_{C a}$ to $\beta$-adrenergic agonists fits well with these data. Based on these published data, we speculate that thyroid hormone maintains $\beta$-adrenergic responsiveness in rabbit ventricular myocytes during primary culture by maintaining the expression of several proteins involved in modulating the $\beta$-adrenergic signaling pathway.

In summary, our results demonstrate that neonatal ventricular myocytes retain basic electrophysiologic properties in short-term culture as assessed by the whole-cell voltage clamp technique. In addition, $\beta$-adrenergic responsiveness of transmembrane L-type calcium channels is preserved in the presence physiologic levels of $\mathrm{T}_{3}$. We propose that this in vitro model of the neonatal myocardium is appropriate for evaluating the $\beta$-adrenergic signaling cascade in a controlled environment amenable to experimental manipulation.

Acknowledgment. The authors thank Bo Kim for secretarial assistance.

\section{REFERENCES}

1. Klein I 1990 Thyroid hormone and the cardiovascular system. Am J Med 88:631-637

2. Morkin E, Flink IL, Goldman S 1983 Biochemical and physiologic effects of thyroid hormone on cardiac performance. Prog Cardiovasc Dis 25:435-464

3. Dillmann WH 1990 Biochemical basis of thyroid hormone action in the heart. Am J Med 88:626-630

4. Gustafson TA, Bahl JJ, Markham BE, Roeske WR, Morkin E 1987 Hormonal regulation of myosin heavy chain and $\alpha$-actin gene expression in cultured fetal rat heart myocytes. J Biol Chem 262:13316-13322

5. Bahouth SW 1991 Thyroid hormones transcriptionally regulate the $\beta_{1}$-adrenergic receptor gene in cultured ventricular myocytes. J Biol Chem 266:15863-15869

6. Rohrer D, Dillmann WH 1988 Thyroid hormone markedly increases the mRNA coding for sarcoplasmic reticulum $\mathrm{Ca}^{2+}$ ATPase in the rat heart. $\mathrm{J}$ Biol Chem 263:6941-6944
7. Rapiejko P.J, Watkins DC, Ros M, Malbon CC 1989 Thyroid hormones regulate G-protein f-subunit mRNA expression in vivo. J Biol Chem 264:16183-16189

8. Hawthorne MH, Gengo P, Wei XY, Rutledge A, Moran JF, Gallant S, Triggle DJ 1988 Effects of thyroid status on $\beta$-adrenoceptors and calcium channels in rat cardiac and vascular tissue. Arch Pharmacol 337:539-544

9. Segal J 1990 Calcium is the first messenger for the action of thyroid hormone at the level of the plasma membrane: first evidence for an acute effect of thyroid hormone on calcium uptake in the heart. Endocrinology 126:2693-2702

10. Binah O, Rujinstein I, Gilat E 1987 Effects of thyroid hormone on the action potential and membrane currents of guinea pig ventricular myocytes. Pflugers Arch 409:214-216

11. Kim D, Smith TW, Marsh JD 1987 Effect of thyroid hormone on slow calcium channel funition in cultured chick ventricular cells. J Clin Invest 80:88-94

12. Huynh TV, Chen F, Wetzel GT, Friedman WF, Klitzner TS 1992 Developmental changes in membrane $\mathrm{Ca}^{2+}$ and $\mathrm{K}^{+}$currents in fetal, neonatal, and adult rabbit ventricular myocytes. Circ Res 70:508-515

13. Hamill OP, Marty A, Neher E, Sakmann B, Sigworth FJ 1981 Improved patch- clamp techniques for high-resolution current recording from cells and cell free membrane patches. Pflugers Arch 391:85-100

14. Wetzel GT, Chen F, Friedman WF, Klitzner TS 1991 Calcium current measurements in acutely isolated neonatal cardiac myocytes. Pediatr Res 30:83-88

15. Wetzel GT, Chen F, Klitzner TS $1993 \mathrm{Ca}^{2+}$ channel kinetics in acutely isolated fetal, neonatal and adult rabbit cardiac myocytes. Circ Res 72:1065-1074

16. Marty A, Neher E 1983 Tight seal whole cell recording. In: Sakmann B, Neher E (eds) Single-Channel Recording. Plenum Press, New York, pp 107-122

17. DeGroot LJ, Larsen PR, Refetoff S, Stanbury JB 1984 The Thyroid and Its Diseases. John Wiley \& Sons, New York, pp 36-117

18. Abuid J, Klein AH, Foley Jr TP, Larsen PR 1974 Total and free triiodothyronine and thyroxine in early infancy. J Clin Endocrinol Metab 39:263-268

19. Borges M, Lanes R, Moret LA, Balochi D, Gonzalez S 1985 Effect of asphyxia on free thyroid hormone levels in full term newborns. Pediatr Res 19:1305-1307

20. Nagashima K, Onoda K, Suzuki S, Sakaguchi M, Kuroume T 1985 Reevaluation of thyroid function in low birth weight infants based on free triiodothyronine and triiodothyronine. Biol Neonate 48:341-345

21. Decker ML, Simpson DG, Behnke M, Cook MG, Decker RS 1990 Morphological analysis of contracting and quiescent adult rabbit cardiac myocytes in long-term culture. Anat Rec 227:285-299

22. Foster KA, McDermott PJ, Robishaw JD 1991 The effect of culture and membrane potential on $G_{o \alpha}$ expression in neonatal rat cardiac myocytes. Mol Cell Biochem 104:63-72

23. McDermott l'J, Rothblum LI, Smith SD, Morgan HE 1989 Accelerated rates of ribosomal RNA synthesis during growth of contracting heart cells in culture. J Biol Chem 264:18220-18227

24. Williams LT, Lefkowitz RJ, Watanabe AM, Hathaway DR, Besch HR Jr 1977 Thyroid horrnone regulation of beta adrenergic receptor number. J Biol Chem 252:2787-2789

25. Collins S, Ostrowski J, Lefkowitz RJ 1993 Cloning and sequence analysis of the human $\beta_{1}$-adjenergic receptor 5 '-flanking promoter region. Biochim Biophys Acta 1172:171-174

26. Waisberg M, Shainberg A 1992 Characterization of muscarinic cholinergic receptors in intact myosardial cells in vitro. Biochem Pharmacol 43:2327-2334 